\title{
Identification of Thr241Met Polymorphisms of the XRCC3 Gene in People with Gastric Cancer in the Amazon Region, Brazil
}

\author{
Lobato LL, Da Silva Cabral S, Vanzeler TL, Do Nascimento RE*, Picanço OM and Do Nascimento Rodrigues AS \\ Laboratory of Molecular Biology of the Federal University of Amapá-UNIFAP, Biological Sciences Course Macapá, Amapá, Brazil
}

\begin{abstract}
XRCC3 Thr241Met polymorphism has been associated with cancer susceptibility. Studies have shown a relationship between Thr241Met polymorphism and gastric cancer. The present study was aimed at examining the presence of XRCC3 Thr241Met polymorphism in patients diagnosed with gastric cancer in the city of Macapá. We analyzed 150 DNA samples, of which 100 comprised the control group and 50 were case patients. Our findings revealed that $76 \%$ of case samples had the Thr/Met genotype (OR (Cl 95\% 54.29 (18.84-156.38) p $\leq 0.0001)$ whereas in the control group, the same genotype represented $7 \%$. Also, most gastric cancer patients with XRCC3 241Met polymorphism were heterozygotes. Given the small sample size in this study, a larger number of patients will be analyzed.
\end{abstract}

Keywords: X-ray; XRCC3 gene; Prostate cancer; Gastric cancer

\section{Introduction}

The X-ray repair cross-complementing group 3 (XRCC3) gene is considered one of the most important DNA repair genes. Consisted of 7 exons located at $14 \mathrm{q} 32.3$ on the human chromosome, it encodes a 346-amino acid protein with the same name. This protein, by interacting with Rad51, repairs double-strand breaks (DSBs) by homologous recombination (HR), and can also participate in the last stages of recombination, aiding the stabilization of the nucleoprotein complex and the formation of heteroduplex DNA [1-10]. Several molecular and epidemiological studies have already been conducted to examine the role of polymorphism in the XRCC3 gene in various neoplasms. The exchange from $\mathrm{C}$ to $\mathrm{T}$ in the exon 7 (C18067T, rs861539) has been the most investigated polymorphism, as it results in the substitution of threonine to methionine at position 241 [11-13]. This variant has been associated with some types of cancer, such as breast, stomach [14,15], lung [16,17], bladder [18], colorectal [19], as well as melanoma [20] and carcinoma of squamous cells of the head and neck [21].

Stomach cancer, despite a decreasing incidence since the 1950s, is still the fourth most common malignant neoplasm and the second largest cause of cancer death worldwide, since survival rates have not changed significantly in the last decades as a result of the high lethality of the disease [22-25]. It is more frequent in developing countries and in the age group over 50 years, with higher rates in men than in women by a ratio of 2: 1 . Incidence is high in Brazil, although rates have been declining, mortality is still elevated compared to those of other countries with the same epidemiological profile. The estimate for this year, according to the report Estimates: Incidence of Cancer in Brazil 2016 of the National Cancer Institute (Instituto Nacional do CâncerINCA), is 12,920 new cases of gastric cancer for men and 7,600 for women. When non-melanoma skin tumors are excluded, gastric cancer is the second most frequent type in men, after prostate cancer in the north and northeast regions, and the fourth most frequent, in the same regions, in women [26-30]. According to the Mortality Information System (Sistema de Informação de Mortalidade - SIM), the number of deaths reported in 2013 was 14,182, of which 9,142 were men and 5,040 were women [31].

Studies, however, indicate that, even under the same environmental conditions, different individuals do not have the same risk to develop this disease. Genetic and epigenetic changes are involved in its development and progression, and although there is no consensus as to the number of genes playing a role in the neoplastic process, several polymorphisms may be associated with the risk of cancer development through the uncontrolled expression of oncogenes and inactivation of tumor suppression genes [1,3]. A better understanding of these genetic factors can broaden methods for the prevention and screening of this diseases, such as the early diagnosis of unsuspected young patients or lesions mistaken as benign diseases $[22,24,30]$. Given the high incidence and mortality rates of gastric cancer in Brazil, especially in the northern region, the present study was aimed at examining the presence of XRCC3 thr241Met polymorphism in patients diagnosed with gastric cancer in the city of Macapá, in the Amazon region, northern Brazil.

\section{Materials and Methods}

The case-control study was carried out in the city of Macapá, state of Amapá, Brazil. The total population consisted of 150 DNA samples, of which 100 were healthy individuals (controls) and 50 of patients diagnosed with gastric cancer and treated at the High Complexity Oncology Unit (Unidade de Alta Complexidade em OncologiaUNACON) of Dr. Alberto Lima Clinical Hospital and the Institute of Hematology and Hemotherapy of Amapá (HEMOAP). The study was approved by the Research Ethics Committee (REC) of the Federal University of Amapá (UNIFAP) and was carried out in accordance with the Helsinki Principle Declaration. All individuals signed the Informed Consent Form (ICF).

\section{Genotype Analysis}

After obtaining ICFs, the collected samples were sent to the Laboratory of Molecular Biology and Biotechnology of the Biological

*Corresponding author: Dr. Ártemis Socorro do Nascimento Rodrigues, Laboratory of Molecular Biology of the Federal University of Amapá-UNIFAP, Biological Sciences Course Macapá, Amapá, Brazil, Tel: 559633121767; E-mail: artemis@unifap.br

Received August 24, 2017; Accepted September 27, 2017; Published September 30, 2017

Citation: Lobato LL, Da Silva Cabral S, Vanzeler TL, Do Nascimento RE, Picanço OM, et al. (2017) Identification of Thr241Met Polymorphisms of the XRCC3 Gene in People with Gastric Cancer in the Amazon Region, Brazil. J Mol Genet Med 11: 290 doi:10.4172/1747-0862.1000290

Copyright: ( 2017 Lobato LL, et al. This is an open-access article distributed under the terms of the Creative Commons Attribution License, which permits unrestricted use, distribution, and reproduction in any medium, provided the original author and source are credited 
Sciences Program of the Federal University of Amapá-UNIFAP, where they were analyzed with molecular techniques to identify XRCC3 Thr241Met polymorphisms.

The procedure to isolate the DNA from the samples of the participants followed the protocol recommended by the manufacturer (KLONILIFE) of the MiniSpin DNA Kit. Samples were amplified and analyzed by PCR-RFLP, the amplification reaction of the Polymerase Chain Reaction (PCR) of the XRCC3 gene was obtained according to Shen et al. The primers used to amplify the $208 \mathrm{bp}$ fragment were 241F: 5-GCTGTCTCGGGGCATGGCTC-3 and 241R: 5 ACGAGCTCAGGGGTGCAACC-3. The enzyme used was Nla III (New EnglandBiolabs, Beverly, MA). The PCR conditions consisted of $25 \mu \mathrm{l}$ containing $1.0 \mu \mathrm{l}$ of each primer, $1.0 \mu \mathrm{l}$ of genomic DNA, $0.5 \mu \mathrm{l}$ of Taq DNA polymerase, $14.5 \mu \mathrm{l} \mathrm{H} \mathrm{O}_{2}, 5 \mathrm{ul}$ of buffer solution, 2 ul dNTP. The amplification cycle was carried out at $94^{\circ} \mathrm{C}$ for 5 minutes, 30 cycles of $94^{\circ} \mathrm{C}$ for 30 seconds, $59^{\circ} \mathrm{C}$ for 30 seconds and $72^{\circ} \mathrm{C}$ for 1 minute, final extension of 10 minutes at $72^{\circ} \mathrm{C}$ and $4^{\circ} \mathrm{C}$. After the amplification reaction, $10 \mu$ of the PCR product were digested with $1 \mu$ of the enzyme Nla III (New England Biolabs, Beverly, MA), $1.0 \mu \mathrm{l}$ of the buffer, $2 \mu \mathrm{l}$ of sterile water at $37^{\circ} \mathrm{C}$ overnight and subsequently electrophoresed to identify the fragments.

\section{Statistical Analysis}

The comparison between the genotype frequencies of the control and case samples was carried out with the statistical software Bio Estat 5.3 (Ayres, M. Pará, Brazil), where the odds ratios (OR) with a $95 \%$ confidence interval (CI) were calculated.

Our results revealed that $76 \%$ of cases had the Thr/Met genotype, while in control samples, this genotype represented $7 \%$. For the genotype $\mathrm{Thr} / \mathrm{Thr}$, the percentages found were $9 \%$ and $90 \%$ for case and control samples, respectively. The genotype Met/Met represented $6 \%$ of cases and $3 \%$ of control samples.

The population is in disequilibrium, as the number of observed cases differed from the expected based on the Hardy-Weinberg equilibrium (Tables 1 and 2).

\section{Discussion}

The present study was conducted in the city of Macapá, located in the Amazon region of northern Brazil and was aimed at examining the presence of XRCC3 Thr241Met polymorphism in DNA samples of patients diagnosed with gastric cancer. In different epidemiological studies, this polymorphism has been associated with the development

\begin{tabular}{|c|c|c|c|c|c|}
\hline \multirow{2}{*}{ Polymorphisms } & \multicolumn{2}{|c|}{ Cases } & \multicolumn{2}{|c|}{ Controls } & \multirow{2}{*}{ OR (CI 95\%) } \\
\hline & $\mathbf{N}^{\circ}$ & $\%$ & $\mathbf{N}^{\circ}$ & $\%$ & \\
\hline Thr/Thr & 9 & 18 & 90 & 90 & Refererence \\
\hline Thr/Met & 38 & 76 & 7 & 7 & $54.29(18.84-156.38) p \leq 0.0001$ \\
\hline Met/Met & 3 & 6 & 3 & 3 & $10.00(1.7537-57.0225) p=0.0165$ \\
\hline Thr/Met e & \multirow{2}{*}{41} & \multirow{2}{*}{82} & \multirow{2}{*}{10} & \multirow{2}{*}{10} & \multirow{2}{*}{$41.00(15.49-108.52) p<0.0001$} \\
\hline Met/Met & & & & & \\
\hline
\end{tabular}

Table 1: Results of the frequency of the gene XRCC3 in cases and controls.

\begin{tabular}{|c|c|c|c|c|}
\hline $\begin{array}{c}\text { XRCC3 } \\
\text { Thr241Met }\end{array}$ & Observed & Expected* & $\begin{array}{c}\text { Hardy-Weinberg } \\
\text { Equilibrium }\end{array}$ & G Test (IC 95\%) \\
\cline { 2 - 3 } Thr/Thr & 9 & 16 & & \\
\hline Thr/Met & 38 & 25 & $\mathrm{~N}=0.0001$ & $\mathrm{p}=0.01$ \\
\hline Met/Met & 3 & 10 & & \\
\hline
\end{tabular}

*Expected cases based on the distribution of the Hardy-Weinberg equilibrium.

Table 2: Distribution of Hardy-Weinberg and $G$ test. of several malignant neoplasms, such as melanoma [32], thyroid cancer [33], osteosarcoma [34], and hepatocellular carcinoma [35]

The gene XRCC3 plays an important role in the repair mechanism by homologous recombination of double stranded DNA (DSB) caused by ionizing radiation and reactive oxygen species, which are one of the most harmful causes of damage and often lead to cellular apoptosis and loss of genetic material. Given the importance of this mechanism in DNA repair, genetic polymorphism might modulate the risk of developing many types of cancer $[1,36,37]$.

The study of this polymorphism in specific populations is justified by the great regional variation regarding its role in the risk of developing cancer. This same research group previously found strong evidence that this polymorphism may be associated with cancer in this population [38].

Compared to breast cancer, Lee et al. conducted a meta-analysis and found a low association between polymorphism and susceptibility to this neoplasm among Korean women. However, Qureshi et al. reported that among Pakistani women, the risk is increased by the presence of this polymorphism [39].

In our study, $18 \%$ of gastric cancer patients had the $\mathrm{Thr} / \mathrm{Thr}$ genotype against $90 \%$ of the control samples, as expected for this wild genotype, demonstrating its higher occurrence in healthy individuals than those diagnosed with cancer $[36,40]$.

The heterozygous genotype (Thr/Met) was found in 76\% (OR 54.29 (18.84-156.38) $\mathrm{p} \leq 0.0001)$ of gastric cancer patients. Our results confirm the the results obtained in the meta-analysis by Fang et al. [2] that revealed the same pattern in all 6 studies analyzed, with heterozygosis associated with the highest susceptibility to develop gastric cancer. This author also reported that in different world populations, Thr241Met SNP has a high inter-ethnic variation. Thus, a genomic control of ancestry in association studies is recommended, since the Brazilian population has a high rate of miscegenation. Consequently, ethnicity may cause differences among groups analyzed, and could lead to incorrect interpretations of the results [41,42].

Our findings support other studies already conducted on the association between XRCC3 polymorphism and the risk of gastric cancer. Although polymorphic genotype was found at a high frequency in the patients examined, further molecular studies are needed on the Thr241Met genotype and the risk of developing gastric cancer in this and other populations for greater reliability between the association of this polymorphism and the risk of gastric cancer.

In the meta-analysis carried out by Cheng et al. [1], when studies were stratified as Caucasians Asians, and other population studies, this polymorphism was inversely associated with gastric cancer in all genetic models between Asians and non-Asians. In addition, significant differences in 241Thr allele frequency were also observed among Asians (73.94\%/84.83\% in patients/controls) and non-Asians. The frequency of this allele in Asians is higher than in Caucasians (63.42\% / 62.30\%) and Brazilians (69.06\%/64.67\%). Thus, various genetic backgrounds may cause this discrepancy or different populations may have distinct patterns of linkage disequilibrium [1].

The wild genotype Thr/Thr, present in $90 \%$ of the control group, is in agreement with the expected for this group of healthy individuals $[4,36]$.

Regarding the Met/Met genotype, low percentages (3\% and 6\%) were observed in both control and case groups. These results are also consistent with those reported in the literature. 
Citation: Lobato LL, Da Silva Cabral S, Vanzeler TL, Do Nascimento RE, Picanço OM, et al. (2017) Identification of Thr241Met Polymorphisms of the XRCC3 Gene in People with Gastric Cancer in the Amazon Region, Brazil. J Mol Genet Med 11: 290 doi:10.4172/1747-0862.1000290

\section{Conclusion}

Our study demonstrated that most gastric cancer patients analyzed exhibited XRCC3 241met polymorphism. Given the small sample size analyzed, a larger number of patients will be analyzed.

Further studies are needed involving multiple genes and more control of selected samples, since exposure to environmental factors, as well as genetic changes in other genes, acting alone or interacting with each other, may increase the risk of developing gastric cancer.

\section{References}

1. Cheng S, Wang L, Wang L, Wang Z (2015) Association of XRCC3 Gene rs861539 polymorphism with gastric cancer risk: Evidence from a case-control study and a meta-analysis. Int J Clin Exp Pathol 8: 1911-1919.

2. Fang F, Wang J, Yao L, Yu XJ, Yu L, et al. (2011) Relationship between XRCC3 T241M polymorphism and gastric cancer risk: A meta-analysis. Med Oncol 28: 999-1003.

3. http://www.cancer.org/research/cancerfactsstatistics/cancerfactsfigures2016/ index.

4. Duarte MC, Colombo J, Rossit AR, Caetano A, Borim AA, et al. (2005) Polymorphisms of DNA repair genes XRCC1 and XRCC3, interaction with environmental exposure and risk of chronic gastritis and gastric cancer. World J Gastroenterol 14: 6593-6600.

5. Christmann M, Tomicic MT, Roos WP, Kaina B, et al. (2003) Mechanisms of human DNA repair: An update. Toxicology 193: 33-34.

6. Arregi (2009) Perfil Clínico-Epidemiológico das Neoplasias de Estômago Atendidas no Hospital do Câncer do Instituto do Câncer do Ceará, no período 2000-2004. Revista Brasileira de Cancerologia 55: 121-128.

7. Brenneman MA, Wagener BM, Miller CA, Allen, C, Nickoloff JA (2002) XRCC3 controls the fidelity of homologous recombination: Roles for XRCC3 in late stages of recombination. Mol Cell 10: 387-395.

8. Thompson LH, Schild D (2002) Recombinational DNA repair and human disease. Mutat Res 509: 49-78.

9. Schild D, Lio YC, Collins DW, Tsomondo T, Chen DJ, et al. (2000) Evidence for simultaneous protein interactions between human RAD-51 paralogs. J Biol Chem 275: 16443-16449.

10. Duarte MC, Colombo J, Rossit ARB, Silva AE (2005) Polymorphisms of the DNA repair genes XRCC1 and XRCC3 in a Brazilian population. Genet Mol Biol 28: 397-401.

11. Qin XP, Zhou Y, Chen Y, Wu XT (2014) XRCC3 Thr241Met polymorphism and gastric cancer susceptibility: A meta-analysis. Clinics Res Hepatol Gastroenterol 38: 226-234.

12. Han S (2006) DNA repair gene XRCC3 polymorphisms and cancer risk: A meta-analysis of 48 case-control studies. Euro J Human Genet 14: 1136-1144

13. Krupa R, Sliwinski T, Wisniewska-Jarosinska M, Chojnacki J, Wasylecka $M$ (2011) Polymorphisms in RAD51, XRCC2 and XRCC3 genes of the homologous recombination repair in colorectal cancer- A case control study. Mol Biol Rep 38: 2849-2854.

14. Jemal A, Bray F, Center MM, Ferlay J, Ward E (2011) Global cancer statistics. CA Cancer J Clin 61: 69-90.

15. Laurén $P$ (1965) The two histological main types of gastric carcinoma: Diffuse and socalled intestinal-type carcinoma. Acta Pathol Microbiol Scand 64: 31-49.

16. Lopasso FP (2014) Gastric cancer. A fleeting glimpse at its genetic evidences. Arq Gastroenterol 51: 77-78.

17. Manuguerra M, Saletta F, Karagas MR, Berwick M, Veglia F, et al. (2006) XRCC3 and XPD/ERCC2 single nucleotide polymorphisms and the risk of cancer: A huge review. Am J Epidemiol 164: 297-302.

18. Andrew AS, Karagas MR, Nelson HH, Guarrera S, Polidoro S, et al. (2008) DNA repair polymorphisms modify bladder cancer risk: a multifactor analytic strategy. Human Heredity 65: 105-118.

19. Resende ALS (2006) Dieta e Câncer Gástrico: Aspectos Históricos Associados ao Padrão de Consumo Alimentar no Estado do Pará. Rev Nutr 19: 511-519.
20. He X, Wei W, Li JL, Shen XL, Ding DP (2013) Association between the XRCC3 T241M polymorphism and risk of cancer: Evidence from 157 case-control studies. Gene 523: 10-19.

21. Yoon $\mathrm{H}$, Kim N (2015) Diagnosis and management of high risk group for gastric cancer. Gut and Liver 9: 5-17.

22. Zhang S, Lee DS, Morrissey R, Aponte-Pieras JR, Rogers AB (2014) Early or late antibiotic intervention prevents Helicobacter pylori- induced gastric cancer in a mouse model. Cancer Lett 355: 106-112.

23. Hamashima C (2014) Current issues and future perspectives of gastric cancer screening. World J Gastroenterol 20: 13767-13774.

24. Latorre MROLA (1997) Mortalidade por Câncer de Estômago no Brasil: Análise do Período de 1977 a 1989. Cad Saúde Publ 13: 67-78.

25. http://www.inca.gov.br/estimativa/2016/estimativa-2016-v11.pdf. Acessado em: $26 / 03 / 16$.

26. http://bvsms.saude.gov.br/bvs/publicacoes/saude_brasil_2013_analise_ situacao_saude.pdf.

27. Vinagre RMDF (2011) Determination of strains of Helicobacter pylori and of polymorphism in the Interleukin-8 gene in patients with stomach cancer. Arq Gastroenterol 48: 46-51.

28. Silva GA (2011) Tendência da Mortalidade por Câncer nas Capitais e Interior do Brasil entre 1980 e 2006. Rev Saúde Pública 45: 1009-1018.

29. Oliveira JFP (2012) Câncer de Estômago: Tendência da Incidência e Mortalidade no Município de Fortaleza, Ceará. Cad. Saúde Colet 20: 359-66.

30. Hanahan D, Weinberg AR (2011) Hallmarks of cancer: The next generation Cell 144: 646-674

31. http://www.nature.com/nature/journal/v513/n7517/full/nature13480.html

32. Gent VDC, Hoeijmakerss JH, Kanaar, R (2001) Chromosomal stability and the DNA double-stranded break connection. Nat Rev Genet 3: 196-206.

33. Gök I, Baday M, Cetinkunar S, Kilic K, Bilgin BC, et al. (2014) Polymorphisms in DNA repair genes XRCC2 and XRCC3 risk of gastric cancer in Turkey. Bosn J Basic Med Sci 14: 214-218.

34. Su Y, Zhang H, Xu F, Kong J, Yu H (2015) DNA repair gene polymorphisms in relation to non-small cell lung cancer survival. Cell Physiol Biochem 36: 1419 1429.

35. Cabral SS, Lobato L, Nascimento RE, Rodrigues ASN (2016) Association between XRCC3 Thr241Met polymorphism and the rick of cancer in Northern Brasil. BJMMR 15: 7: 1-6.

36. Lee SA, Lee KM, Park SK, Choi JY, Kim B, et al. (2007) Genetic polymorphism of XRCC3 Thr241Met and breast cancer risk: Case-control study in Korean women and meta-analysis of 12 studies. Breast Cancer Res Treat 103: 71-76.

37. He X, Wei W, Li JL, Shen XL, Ding DP, et al. (2013) Association between the XRCC3 T241M polymorphism and risk of cancer: Evidence from 157 casecontrol studies. Gene 523: 10-19.

38. Dianov GL, Sleeth KM, Dianova II, Allinson SL (2003) Repair of abasic sites in DNA. Mut Res 531: 157-163.

39. Lima J (2006) Estudo do polimorfismo genético no gene p53 (códon 72) em câncer colorretal. Arq Gastroenterol 43: 8-13.

40. World Health Organization (2012) International Agency for Research on Cancer. Globocan, Geneva, Switzerland.

41. Filho WV, Zago M (2005) Modern cancer epidemiological research: Genetic polymorphisms and environment. Rev de Saúde Pública 39: 490-497.

42. Wang W, Li YF, Sun XW, Chen YB, Li W, et al. (2010) Prognosis of 980 patients with gastric cancer after surgical resection. Chin J Cancer 29: 23-30. 